\title{
A STUDY OF DRUG UTILIZATION IN PATIENTS OF CARCINOMA BREAST RECEIVING SYSTEMIC CHEMOTHERAPY IN TERTIARY CARE HOSPITALS
}

\author{
SUCHI SHAH ${ }^{1 *}$, ANIL SINGH ${ }^{2}$, SHAILESH MUNDHAVA ${ }^{2}$ \\ ${ }^{1}$ Department of Pharmacology, BJ Medical College, Ahmedabad. ${ }^{2}$ Department of Pharmacology, PDU Medical College, Rajkot. \\ E-mail: suchi.shah1990@gmail.com
}

Received: 17 January 2021, Revised and Accepted: 26 February 2021

\begin{abstract}
Objective: The objective of the study is to study drug utilization in patients with breast carcinoma receiving systemic chemotherapy in government as well as private set-up.

Methods: This was a record-based, retrospective-prospective study, analyzing the prescription pattern of drugs used for systemic chemotherapy in patients diagnosed with carcinoma breast at government teaching hospital (GTH) and private trust hospital (PTH) for 1 year in 600 patients. Patient's demographic, clinical, and therapeutic data were collected from the files and personal interviews and analyzed in Microsoft Excel.

Results: Diagnosis of breast carcinoma was highest in age bracket of 40-49 years (32.33\% GTH and 32.67\% PTH), and the most common presenting symptom was painless lump (76.33\% GTH and 83\% PTH). In GTH, most frequently prescribed regimen was $4 \mathrm{AC} \rightarrow 4 \mathrm{~T} \rightarrow \mathrm{RT}(17.33 \%)$. In PTH, most commonly prescribed regimen was 6FEC $\rightarrow$ RT (19.33\%). Highest prescribed drugs were A (32.8\%), C (29.12\%), and F (20.24\%) in GTH and A (32.26\%), F (31.68\%), and E (16.45\%) in PTH. Average number of drugs prescribed per prescription was 12.55 and 11.37 ; percentage of chemotherapeutic agents prescribed by generic name was 100 and 95.02, and from the WHO essential drug list (2015) was 96.43 and 82.77 in GTH and PTH, respectively ( $\mathrm{A}=$ Cyclophosphamide, $\mathrm{C}=$ Doxorubicin, $\mathrm{T}=$ Taxanes [Paclitaxel/Docetaxel], $\mathrm{F}=5$-fluorouracil, $\mathrm{E}=\mathrm{Epirubicin}, \mathrm{RT}=\mathrm{Radiotherapy,}$ $\rightarrow$ followed by, the number indicates chemotherapy cycle).
\end{abstract}

Conclusion: The study results can help in generating local data regarding drug use pattern of the systemic chemotherapeutic agents in breast cancer patients and promote rational drug use.

Keywords: Carcinoma breast, Drug utilization, Systemic chemotherapy, Rational drug use.

(C) 2021 The Authors. Published by Innovare Academic Sciences Pvt Ltd. This is an open access article under the CC BY license (http://creativecommons.org/ licenses/by/4.0/) DOI: http://dx.doi.org/10.22159/ajpcr.2021v14i4.40826. Journal homepage: https://innovareacademics.in/journals/index.php/ajpcr

\section{INTRODUCTION}

A neoplasm is defined as a disorder of cell growth that is triggered by a series of acquired mutations affecting a single cell and its clonal progeny resulting in excessive proliferation that is independent of physiologic growth stimulus [1]. By 2040, the global burden of cancer is expected to grow to 27.5 million new cases which can lead to 16.3 million cancer deaths [2].

Breast cancers are clonal proliferations that arise from ductal or lobular breast cells with multiple genetic aberrations. This process is influenced by hormonal exposure, inherited susceptibility of genes, and environmental factors or their interplay [3]. The most common cancer in India is breast cancer (14\% of the total cases) and it is one of the leading causes of cancer deaths (11.1\% of the total cases) [4]. The treatment modalities for breast cancer are surgery, radiotherapy, and chemotherapy: selection of which depends on tumor size, number of lymph node involvement, and overall health of the patient [5].

Decision about optimal treatment pattern for breast cancer depends on trial data of efficacy and safety of chemotherapeutic agent, along with women's treatment preferences and socioeconomic status [6]. While effectiveness and safety of breast cancer therapies are thoroughly studied in randomized clinical trials, only few data are available for the same in daily practice settings. Furthermore, some serious adverse drug reactions are only identified after cancer chemotherapy drugs have widely been used in clinical practice (as long as after 36 years of FDA approval), which may be missed in clinical trial set-up [7].
Drug utilization research is defined as the marketing, distribution, prescription, and use of drugs in a society, with special emphasis on the resulting medical, social, and economic consequences, which provides very useful information regarding drug use pattern, rationality of drug usage, intervention to improve drug use, and quality control of drug use [8]. Systemic chemotherapy is being used extensively in breast cancer management, so it is important to know the utilization pattern of these agents in tertiary care hospitals.

\section{METHODS}

It was a record-based, observational retrospective as well as prospective study analyzing the prescription pattern of drugs used for systemic chemotherapy in patients diagnosed with carcinoma breast at 2 study sites: (a) government teaching hospital (GTH) and (b) private trust hospital (PTH) for 1 year (2016-2017) in 600 patients. This study was approved by the Institutional Ethics Committee of P.D.U. Govt. Medical College, Rajkot. (No.) PDUMCR/ IEC/7796/2016.

The study included as follows:

a. All patients with carcinoma breast receiving chemotherapy for Stage 1,2 , and 3

b. Patient receiving chemotherapy before surgery (neoadjuvant)

c. The patients who have received the chemotherapy in the past years.

The patients with end-stage metastatic disease (stage 4) were excluded from the study. 
Patient's demographic, clinical, and therapeutic data were collected from the files and personal interviews after obtaining written informed consent. No intervention was done in the treatment of the patients by the investigator. Recorded data were entered and analyzed using descriptive statistics in Microsoft Office Excel-2013.

\section{RESULTS}

The present study was carried out to evaluate the drug utilization pattern of systemic chemotherapy given to patient with breast carcinoma at 2 sites, analyzing the data of 600 patients over the period of 1 year. The most common age group for breast cancer patients in both groups - GTH and PTH was $40-49$ years (32.33\% and $32.67 \%$ respectively). Most women were in post-menopausal group in GTH as well as PTH (57.33\% and 64.66\%). Painless lump was the most common presenting symptom in both groups (76.33\% in GTH and $83 \%$ in PTH).

Invasive ductal carcinoma, not otherwise specific, was the most common histological type of tumors seen in $73.33 \%$ in GTH and $80 \%$ in PTH. Majority patients in government set-up presented with tumor stage $3 \mathrm{~B}(27.66 \%)$ and in private $3 \mathrm{~A}(30.33 \%)$. The grade of the tumor, number of lymph nodes positive, and hormone receptor status were not documented in patient records for most of the patients in both the set-ups. $73 \%$ of patients in GTH and 79\% of patients in PTH received adjuvant chemotherapy after modified radical mastectomy.

Table 1 shows percentage of patients receiving Radiotherapy and hormone therapy in both set-ups.

In 10 patients ( 5 in each group), hormone therapy alone was prescribed as treatment. The reasons were old age ( 4 patients), denial to receive chemotherapy ( 2 patients), and reason not justified (4 patients).

In GTH most frequently prescribed regimens were as follows:

1. $4 \mathrm{AC} \rightarrow 4 \mathrm{~T} \rightarrow \mathrm{RT}(17.33 \%)$

2. $6 \mathrm{FAC} \rightarrow \mathrm{HT}:(15.33 \%)$

3. $4 \mathrm{AC} \rightarrow 4 \mathrm{~T}(12.66 \%)$.

In the $\mathrm{PTH}$, most frequently prescribed regimens were as follows:

a. $\quad 6 \mathrm{FEC} \rightarrow \mathrm{RT}(19.33 \%)$

b. $\quad 6$ FAC $(14 \%)$

c. 6 FEC $(12.33 \%)$.

Most frequently prescribed chemotherapeutic agents (\%) in government and private trust hospital are illustrated in Figs. 1 and 2 respectively.

Table 2 shows most commonly prescribed concomitant drugs given in both set-ups.

(A=Cyclophosphamide, $\quad \mathrm{C}=$ Doxorubicin, $\mathrm{T}=$ Taxanes [Paclitaxel/ Docetaxel], $\mathrm{F}=$ 5-fluorouracil, $\mathrm{E}=$ Epirubicin, RT= Radiotherapy, HT=Hormone Therapy, $\rightarrow$ followed by, the number indicates chemotherapy cycle).

WHO prescribing indicators for both- government as well as private set-up are shown in Table 3

\section{DISCUSSION}

In our study, the most common age group for breast cancer patients was 40-49 years in both groups - GTH and PTH. In a study done by Chopra et $a l$, also the most common age group for Indian breast cancer patient was 41-50 [9]. The median age of breast cancer in American population is 62 years [10]. This indicates the age shift of breast cancer occurrence in Indian population compared to the western world. There might be some genetic tendency of Indian population to develop breast cancer earlier or a role of environmental factors which is yet to be explored [11].

Painless lump was the most common presenting symptom. Majority patients in GTH presented with tumor stage 3B (27.66\%) (similar to study
Table 1: Number of patients prescribed radiotherapy/hormone therapy in their treatment regimen

\begin{tabular}{llll}
\hline S. No & $\begin{array}{l}\text { Treatment } \\
\text { modality }\end{array}$ & $\begin{array}{l}\text { Government teaching } \\
\text { hospital (\%) } \mathbf{n = 3 0 0}\end{array}$ & $\begin{array}{l}\text { Private trust } \\
\text { hospital }(\%) \mathbf{n}=\mathbf{3 0 0}\end{array}$ \\
\hline 1. & Radiotherapy & 41.33 & 50.66 \\
2. & $\begin{array}{l}\text { Hormone } \\
\text { therapy }\end{array}$ & 41.99 & 16.66 \\
& $\begin{array}{l}\text { Tamoxifen } \\
\text { Letrozole }\end{array}$ & 16.33 & 8 \\
& 25.66 & 8.66 \\
\hline
\end{tabular}

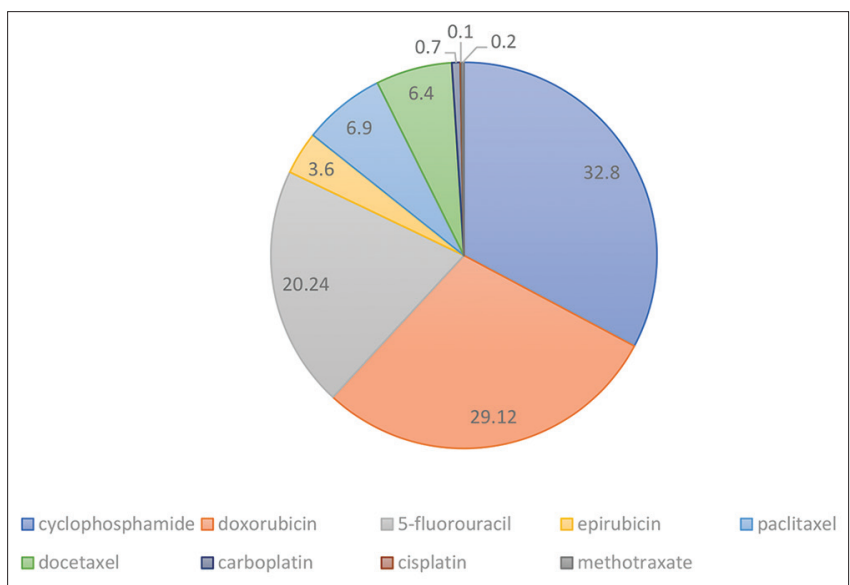

Fig. 1: Most frequently prescribed chemotherapeutic agents (\%) in government teaching hospital

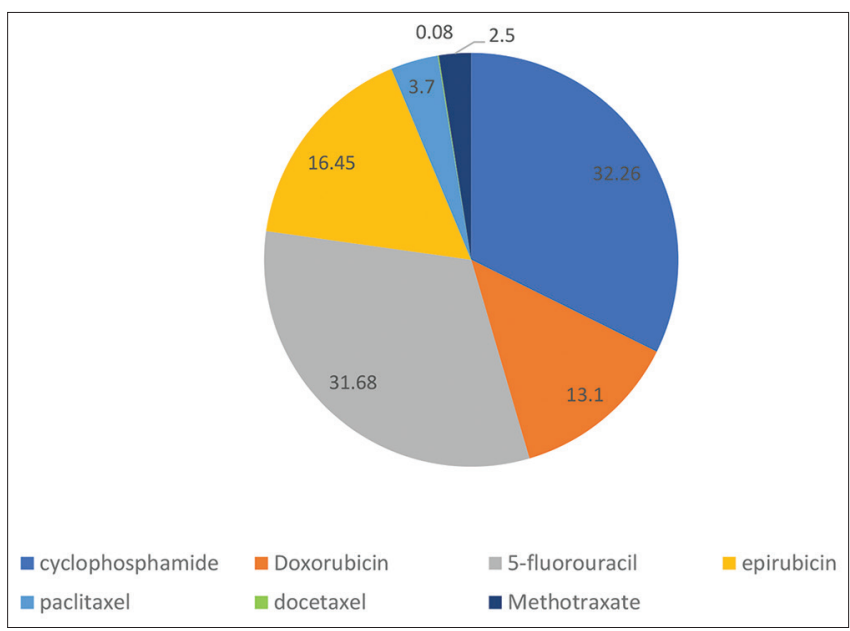

Fig. 2: Most frequently prescribed chemotherapeutic agents (\%) in private trust hospital

by Das et al.) [12] and in private 3A (30.33\%). Late diagnosis carries poor prognosis and high fatalities, indicating the need of sensitization about self-breast examination and screening mammography. The data regarding tumor grade, number of positive lymph nodes, and the hormone receptor status - ER, PR and Her2 - were missing from case sheets for majority of patients in both set-ups. These are important prognostic factors and are useful for specific management of breast cancer [13].

In both set-ups, anthracycline-based chemotherapy regimens (GTH anthracycline + taxanes and PTH anthracycline) were most frequently prescribed. These results are similar with the registry-based study done in Netherlands (76.4\%) [14]. Trastuzumab was not prescribed in both set-ups - reasons being unavailability of Her2 assay and the cost of the drug. $74.1 \%$ patients received trastuzumab (Her2 positive) in the Netherlands [14]. The concomitant drugs are given to prevent and 
Table 2: Most frequently used concomitant drugs

\begin{tabular}{lll}
\hline Drug name & $\begin{array}{l}\text { Government teaching } \\
\text { hospital (\%) } \mathbf{n = 3 0 0}\end{array}$ & $\begin{array}{l}\text { Private trust } \\
\text { hospital (\%) } \mathbf{n = 3 0 0}\end{array}$ \\
\hline Ranitidine & 25.06 & 15.87 \\
Dexamethasone & 24.07 & 32.74 \\
Granisetron & 16.13 & 11.4 \\
Pheniramine & 12.55 & 15.86 \\
maleate & & \\
Metoclopramide & 11.9 & - \\
Ondansetron & 8.86 & 2.29 \\
Palonosetron & - & 4.09 \\
Heparin & - & 16.75 \\
Miscellaneous & 1 & 0.63 \\
\hline
\end{tabular}

Table 3: WHO Prescribing indicators

\begin{tabular}{|c|c|c|c|}
\hline S. No & Prescribing indicators & $\begin{array}{l}\text { Government } \\
\text { teaching hospital } \\
(\%) n=300\end{array}$ & $\begin{array}{l}\text { Private trust } \\
\text { hospital (\%) } \\
n=300\end{array}$ \\
\hline 1 & $\begin{array}{l}\text { Average number of drugs } \\
\text { per prescription }\end{array}$ & 12.55 & 11.37 \\
\hline 2 & $\begin{array}{l}\text { Average number of } \\
\text { chemotherapeutic drugs } \\
\text { per prescription }\end{array}$ & 2.33 & 2.75 \\
\hline 3 & $\begin{array}{l}\text { Average number of } \\
\text { concomitant drugs }\end{array}$ & 10.21 & 8.62 \\
\hline 4 & $\begin{array}{l}\text { Percentage of } \\
\text { chemotherapeutic drugs } \\
\text { prescribed by generic } \\
\text { name }\end{array}$ & 100 & 95.02 \\
\hline 5 & $\begin{array}{l}\text { Total patients receiving } \\
\text { injections }\end{array}$ & 99.44 & 99.62 \\
\hline 6 & $\begin{array}{l}\text { Percentage of } \\
\text { chemotherapeutic drugs } \\
\text { prescribed from WHO } \\
\text { Essential drug list (2015) }\end{array}$ & 96.34 & 82.77 \\
\hline 7 & $\begin{array}{l}\text { Percentage of } \\
\text { chemotherapeutic drugs } \\
\text { prescribed from National } \\
\text { Essential medicine } \\
\text { list (2011) }\end{array}$ & 89.85 & 82.69 \\
\hline 8 & $\begin{array}{l}\text { Percentage of } \\
\text { concomitant drugs } \\
\text { prescribed by generic } \\
\text { name }\end{array}$ & 16.33 & 17.78 \\
\hline 9 & $\begin{array}{l}\text { Percentage of } \\
\text { concomitant drugs } \\
\text { prescribed from WHO } \\
\text { Essential drug list (2015) }\end{array}$ & 71.12 & 68.55 \\
\hline 10 & $\begin{array}{l}\text { Percentage of } \\
\text { concomitant drugs } \\
\text { prescribed from National } \\
\text { Essential medicine } \\
\text { list (2011) }\end{array}$ & 83.67 & 84.41 \\
\hline
\end{tabular}

treat any acute reactions associated with systemic chemotherapeutic agents and are given with each cycle of chemotherapy. Heparin flush in the dose of $2000 \mathrm{IU} / 2 \mathrm{ml}$ was prescribed in almost every cycle in PTH to prevent blockage in the intravenous cannula [15] but was not prescribed in GTH.

In GTH and PTH, a total number of drugs per prescription were high (12.55 and 11.37) but it is justified in breast cancer patients. Percentage of chemotherapeutic drugs prescribed by generic name in GTH and PTH were $100 \%$ and $95.02 \%$, but percentage of concomitant drugs prescribed by generic name was less in comparison $(16.33 \%$ and
$17.78 \%)$. In both set-ups, there was good adherence to the essential medicine lists, both WHO and national.

No data of adverse drug reactions related with chemotherapeutic agents were recorded in the patient case file in GTH and PTH. In GTH, fosaprepitant (NK1 receptor antagonist) was prescribed in 30 patients indicating severe vomiting not controlled by 5-HT3 antagonists. Doxorubicin and daunorubicin can produce cardiotoxicity: acute (reversible) or delayed (congestive cardiac failure due to cardiomyopathy) [16]. Patients with cardiac risk factors should be thoroughly monitored for the side effects when given anthracyclinebased chemotherapy.

\section{Limitation and future prospective}

This study was carried out for only 1 year which is not adequate to report the outcome or disease-free survival in breast cancer patients.

\section{CONCLUSION}

From this study, we get an idea of the drug use pattern of systemic chemotherapeutic agents in carcinoma breast patients along with local demographic pattern of disease. This data can be used to plan other studies like outcome analysis or pharmacoeconomic analysis in the field. These types of studies will provide local clinical practice data and may help in promoting rational drug use and identify long-term adverse effects of the chemotherapeutic agents used for cancer treatment.

\section{AUTHORS' CONTRIBUTIONS}

Suchi Shah was involved in conceptualization, data-collection, formal analysis, writing original manuscript draft, and editing. Shailesh Mundhava was involved in conceptualization, supervision, formal analysis, editing, and reviewing the manuscript. Anil Singh was involved in conceptualization, supervision, formal analysis, reviewing, and editing the manuscript.

\section{CONFLICTS OF INTEREST}

The authors declared no conflicts of interest related to this study.

\section{AUTHORS' FUNDING}

The authors declared that there was no source of funding.

\section{REFERENCES}

1. Kumar V, Abbas AK, Aster JC. Neoplasia. In: Robbins and Cotran Pathologic Basis of Disease. Vol. 1. New Delhi: Elsevier Limited; 2014. p. 265-7.

2. American Cancer Society. Atlanta: The Association. Global Cancer Facts and Figures; 2021. Available from: https://www.cancer.org/research/ cancer-facts-statistics/global.html. [Last accessed on 2021 Jan 07].

3. Lester SC. The breast. In: Kumar V, Abbas AK, Aster JC, editors. Robbins and Cotran Pathologic Basis of Disease. Vol. 2. New Delhi: Elsevier Limited; 2014. p. 1051-4.

4. Dar M, Sharma K. Burden of cancer in India: GLOBOCAN 2018 estimates incidence, mortality, prevalence and future projections of cancer in India. J Emerg Technol Innov Res 2018;6:e505.

5. Bray F, Jemal A, Grey N, Ferlay J, Forman D. Global cancer transitions according to the human development index (2008-2030): A populationbased study. Lancet Oncol 2012;13:790-801.

6. Gennari R, Curigliano G, Rotmensz N, Robertson C, Colleoni M, Zurrida $\mathrm{S}$, et al. Breast carcinoma in elderly women: Features of disease presentation, choice of local and systemic treatments compared with younger postmenopasual patients. Cancer 2004;101:1302-10.

7. Ladewski LA, Belknap SM, Nebeker JR, Sartor O, Lyons EA, Kuzel TC, et al. Dissemination of information on potentially fatal adverse drug reactions for cancer drugs from 2000 to 2002: First results from the research on adverse drug events and reports project. J Clin Oncol 2003;21:3859-66.

8. Maiti R. Drug utilization studies. In: Postgraduate Topics in Pharmacology. $2^{\text {nd }}$ ed. Hyderabad: Paras Medical Books Private Ltd.; 
2015. p. 218-30

9. Chopra B, Kaur V, Singh K, Verma M, Singh S, Singh A. Age shift: Breast cancer is occurring in younger age groups - Is it true? Clin Cancer Invest J 2014;3:526-9.

10. Anderson WF, Pfeiffer RM, Dores GM, Sherman ME. Comparison of age distribution patterns for different histopathologic types of breast carcinoma. Cancer Epidemiol Biomarkers Prev 2006;15:1899-905.

11. Chauhan A, Subba SH, Menezes RG, Shetty BS, Thakur V, Chabra S, et al. Younger women are affected by breast cancer in South India - a hospital-based descriptive study. Asian Pac J Cancer 2011;12:709-11.

12. Das K, Sarkar DK, Karim R, Manna AK. Preoperative ultrasound guided needle localisation for non-palpable breast lesions. Indian J Surg
2010;72:117-23

13. Lester SC. The breast. In: Kumar V, Abbas AK, Aster JC, editors, Robbins and Cotran Pathologic Basis of Disease. Vol. 2. New Delhi: Elsevier Limited; 2014. p. 1051-71

14. Van Herk-Sukel M. Medication Use among Women with Breast Cancer in the Netherlands: Pharmacoepidemiological Studies based on Data from the Eindhoven Cancer Registry-PHARMO Linkage; 2011.

15. Heparin (Flush); 1996-2020. Available from: https://www.drugs.com/ $\mathrm{mtm} /$ heparin-flush.html. [Last accessed on $2021 \mathrm{Jan}$ 07].

16. Tripathi KD. Essentials of Medical Pharmacology. $7^{\text {th }}$ ed. New Delhi: Jaypee Brothers Medical Publishers; 2013. p. 86. 